\title{
PEMBERDAYAAN MASYARAKAT MENGHADAPI MEA MELALUI PELATIHAN KETERAMPILAN DI KOTA MAGELANG
}

\author{
Agrissto Bintang Aji Pradana ${ }^{1}$, Ari Suryawan ${ }^{2}$, Tabah Subekti ${ }^{3}$ \\ Program Studi PGSD \\ Fakultas Keguruan dan Ilmu Pendidikan \\ Universitas Muhammadiyah Magelang
}

Email: ${ }^{1}$ agrisstobintang@gmail.com, ${ }^{2}$ ari.surya_88@yahoo.com, ${ }^{3}$ tabahsubekti2@gmail.com

\begin{abstract}
A preliminary observation revealed that a number of people living near Mount Hill considered to start their business but they were lack of money and skills. This community service was conducted through a training purposed for improving their knowledge about enterpreneurship, motivation and skills on resin craft making. Conducted in November 27, 2016 in Magersari, Magelang, it was aimed at those living in RW VII. It was devided into two steps, preparation and training activities. The preparation covered the coordination with the stakeholders and participants, and the materials preparation. While the training activity provided the introduction of entrepreneurship, motivation and resin crafting experience. SWOT technique was presented in the entrepreneurship discussion activity. Then the crafts they experienced was made of resin. Based on the result, it can be concluded that the training gave them better understanding about entrepreneurship. Besides, they were finally able to create resin crafts. Follow-up was so needed to develop their skills that could be a souvenier business in Mount Tidar.
\end{abstract}

Keywords : Mount Tidar, resin crafts, enterpreneurship

\section{PENDAHULUAN}

Penerapan MEA memberi peluang yang sangat besar kepada setiap warga negara anggota ASEAN untuk melakukan pertukaran informasi, barang, dan jasa. Keadaan tersebut memungkinkan meningkatnya arus perdagangan. Menghadapi MEA ini, tentunya perlu sekali diadakan pembenahan baik dalam bidang pendidikan, ekonomi, sosial, maupun budaya. Indonesia akan dikuasai oleh negara-negara tetangga yang lebih maju apabila tidak mempersiapkan diri sejak dini.

Sesuai dengan visi Presiden Republik Indonesia yakni "Terwujudnya Indonesia yang Berdaulat, Mandiri dan Berkepribadian Berlandaskan Gotong Royong", tidak hanya di bidang ekonomi dan perdagangan tetapi sektor pariwisata juga diharapkan akan memberikan kontribusi besar kepada pemasukan negara serta peningkatan taraf hidup masyarakat. Peningkatan daya saing ini dicapai dengan memanfaatkan potensi yang belum dikelola dengan baik. Hal ini menjadi peluang besar untuk sektor pariwisata untuk mendorong akselerasi pertumbuhan ekonomi nasional. Sehubungan dengan itu, Kementerian Pariwisata Republik Indonesia telah menyusun rencana strategis 2015-2019 yang tertuang dalam Peraturan Menteri Pariwisata No. 29 Tahun 2015. Salah satu renstra tersebut berbunyi "Mengembangkan destinasi pariwisata yang berdaya saing, berwawasan lingkungan dan budaya dalam meningkatkan pendapatan nasional, daerah dan mewujudkan masyarakat yang mandiri.

Pertumbuhan dan pengembangan tujuan wisata diarahkan untuk meningkatkan tidak hanya dari segi kualitas, namun juga kuantitas 
melaui pengembangan destinasi wisata alam, budaya, dan buatan yang berdaya saing antara lain meliputi pengembangan wisata kuliner dan spa, wisata sejarah dan religi, wisata tradisi dan seni budaya, wisata perdesaan dan perkotaan, wisata bahari, wisata ekologi dan petualangan, kawasan wisata, serta wisata konvensi, olahraga dan rekreasi, (Kementerian Pariwisata Republik Indonesia, 2015: 29). Berdasarkan rencana tersebut, pemerintah lebih menekankan pada pengembangan pariwisata dari akar rumput dengan memberdayakan segala aspek pendukung baik alam, seni budaya, religi, olah raga, sejarah, kuliner, maupun sumber daya manusianya. Hal ini selaras dengan rencana Badan Perencanaan Pembangunan Nasional (2014: 3) bahwa jenis pariwisata yang akan diandalkan dalam promosi ke wisatawan mancanegara mencakup:

1. Wisata alam yang terdiri dari wisata bahari, wisata ekologi, dan wisata petualangan.

2. Wisata budaya yang terdiri dari wisata heritage dan religi, wisata kuliner dan belanja, dan wisata kota dan desa.

3. Wisata ciptaan yang terdiri dari wisata MICE \& event, wisata olahraga, dan wisata kawasan terpadu.

Magelang merupakan salah satu tujuan wisata alam dan religi. Sama halnya dengan wisata religi yang lain, Gunung Tidar merupakan tujuan wisata religi di Magelang yang cukup banyak dikunjungi oleh wisatawan domestik. Gunung Tidar merupakan salah satu ikon di Kota Magelang dan dikenal sebagai pakunya Pulau Jawa. Selain itu, pohon-pohonnya berfungsi sebagai paru-paru kota sehingga udara Kota Magelang selalu segar. Di lokasi ini terdapat beberapa makam dan petilasan leluhur masyarakat masyarakat Magelang, salah satunya adalah petilasan penyebar agama Islam di Jawa Tengah yakni petilasan Syekh Subakir dari Persia.

Melihat potensi alam yang dimiliki Gunung Tidar, maka ditawarkan pengembangan untuk daerah wisata dan olah raga di kawasan ini. Kegiatan wisata antara lain wisata religi dengan akses jalan menggunakan jalur yang sudah ada dengan transportasi kereta kuda, stasiun kereta gantung yang menghubungkan Alun-alun - Taman Kyai Langgeng - Gunung Tidar, restoran outdoor di lereng Gunung Tidar dengan view Kota Magelang. Sedangkan kegiatan olah raga antara lain family outbond, terjun payung tandem, serta downhill mountain bike. Saat ini pemanfaatan Gunung Tidar adalah untuk wisata religi dan tempat latihan Akademi Militer. Akses jalan serta fasilitas angkutan umum menuju ke lokasi ini telah tersedia. Selain itu sekarang telah dibangun jalan pintas menuju bukit Tidar tempatnya di belakang terminal lama, (Kantor Penanaman Modal Kota Magelang, 2015). Walaupun belum setenar Candi Borobudur, Wisata Gunung Tidar memberikan manfaat ekonomis kepada masyarakat sekitar. Hal tersebut terlihat dari banyaknya toko oleholeh dan tempat makan yang terdapat di sekelilingnya. Seperti penjelasan di atas, letaknya yang strategis, kemudahan akses jalan, serta tingginya minat masyarakat untuk berziarah menjadi keuntungan yang dapat dimanfaatkan oleh masyarakat sekitar.

Peluang tersebut nampaknya kurang didukung dengan keinginan masyarakat sekitar dalam berwirausaha berbasis keterampilan kerajinan tangan. Program pelatihan keterampilan dari pemerintah dan dinas terkait, dalam hal ini Dinas Koperasi, Perindustrian, dan Perdagangan, dapat dikatakan sudah maksimal namun kurang dimanfaatkan secara optimal oleh masyarakat. Kebermanfaatan menjadi salah satu penyebab minimnya minat masyarakat untuk mengikuti pelatihan. Selama ini pelatihan hanya bertujuan untuk membekali peserta dengan keterampilan, namun tidak mengubah mindset mereka untuk berwirausaha. Produk yang dihasilkan pun kurang mengikuti perkembangan jaman dan pergeseran minat konsumen.

Berdasarkan uraian di atas, kurangnya motivasi dan keterampilan berwirausaha merupakan permasalahan utama yang dihadapi oleh masyarakat sekitar Kawasan 
Wisata Gunung Tidar. Badan Perencanaan Pembangunan Nasional(2014:4) menyatakan bahwa arah kebijakan dan strategi pariwisata Indonesia salah satunya ialah pembangunan industri pariwisata yang diwujudkan melalui:

1. Pembinaan usaha pariwisata bagi masyarakat lokal.

2. Fasilitasi investasi usaha sektor pariwisata, serta

3. Fasilitasi pengembangan dan peningkatan jenjang keterampilan tenaga kerja lokal di bidang wisata;

4. Mendorong terbangunnya sikap/mental penduduk lokal yang ramah terhadap wisatawan.

Sesuai dengan arah kebijakan tersebut, tujuan Pengabdian pada Masyarakat ini ialah memberikan pelatihan yang mampu meningkatkan motivasi dan mental berwirausaha, bekal keterampilan memproduksi kerajinan tangan.

Salah satu kerajinan tangan yang sering dijadikan souvenir adalah kerajinan fiberglass dan resin. Haryono (2011: 11) menyatakan bahwa fiberglass merupakan bahan paduan atau campuran beberapa bahan kimia (bahan komposit) yang terdiri dari cairan resin (water glass), katalis, kalsium karbonat, met/matt, cobalt blue, dan wax (mold release) yang bereaksi dan mengeras dalam waktu tertentu. Fiberglass hampir sama dengan resin. Dalam pelatihan ini, peserta lebih ditekankan pada pemanfaatan resin sebagai bahan dasar. Kartika, dkk (2015: 11) menyebutkan bahwa resin adalah senyawa polimer rantai karbon. Polymer berasal dari kata poly (banyak) dan mer (ikatan). Senyawa polimer rantai karbon dapat didefinisikan sebagai senyawa yang mempunyai banyak ikatan rantai karbon. Resin untuk bahan aksesoris fiberglass, umumnya menggunakan resin bening atau resin butek. Resin bening, biasanya digunakan untuk bentuk yang menonjolkan kebeningannya, seperti untuk aksesoris visor, kap lampu, dan lain-lain sebagai pengganti mika. Selain bahan bakunya yang mudah didapat, kerajinan ini mudah dibuat.

Cara pembuatannya yaitu dengan mencampur kedua bahan tersebut dan menuangkannya ke dalam cetakan. Untuk mempercantik, dapat diisi dengan manik - manik atau benda - benda unik lainnya. Menurut Carlton (1982: 1), bahan-bahan yang dibutuhkan untuk membuat kerajinan resin adalah resin, catalyst, embedments (isian), colorant (pewarna), serta molds (cetakan). Lebih lanjut, Carlton (1982: 2) juga menjelaskan langkah-langkah pembuatannya yakni (1) persiapan; (2) mengukur campuran resin; (3) menambbahkan pewarna; (4) menambahkan katalis; (5) aduk adonan secara merata; (6) tuangkan ke dalam cetakan; (7) biarkan adonan sampai menjadi gel; (8) beri isian; (9) hilangkan gelembung udara pada adonan; (10) tuangkan lapisan tambahan; (11) tunggu hingga mengering; (12) lepaskan adonan dari cetakan.

Kerajinan resin semacam ini dapat dibuat dengan variasi yang menarik. Pada umumnya, pengrajin resin memberi isian berupa serangga yang diawetkan, manikmanik, atau miniatur candi. Resin ini pun dapat diberi campuran warna untuk memperindah tampilan atau dengan memberi campuran glitter pada adonan resin.

Melalui pelatihan pembuatan kerajinan resin ini, masyarakat memperoleh keterampilan pembuatan kerajinan resin. Bahan dan peralatan yang mudah didapat dan harganya yang terjangkau diharapkan dapat menarik minat mereka untuk mengembangkan usaha kerajinan ini. Kemudian, hasil kerajinan resin ini dapat dijual di kawasan Gunung Tidar kepada pengunjung atau peziarah sebagai souvenir. Selain itu, minat dan pengetahuan akan berwirausaha pun meningkat.

\section{METODE PELAKSANAAN}

Permasalahan yang dihadapi warga antara lain adalah keterampilan dan pengetahuan berwirausaha. Oleh karena itu, sudah seharusnya perguruan tinggi melalui penerapan Dharma ke-3 yaitu Pengabdian pada Masyarakat memberikan kontribusi untuk memecahkan persoalan tersebut. Realisasi pemecahan masalah terhadap kerangka pemecahan masalah dilakukan 
melalui peningkatan ketrampilan dalam pelatihan pembuatan kerajinan resin yang diharapkan mampu menumbuhkan jiwa berwirausaha.

Berdasarkan hasil analisis situasi dan kondisi objektif, dapat disimpulkan melalui alur penyelesaian masalah sebagai berikut.

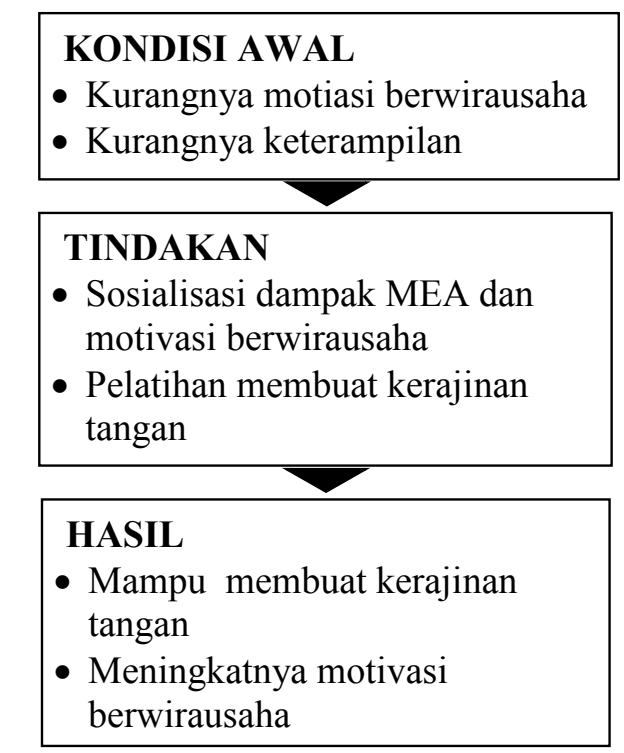

Gambar 1. Kerangka konsep penyelesaian masalah
Dalam rangka mencapai hasil yang telah ditentukan, dilaksanakanlah diskusi dan motivasi wirausaha serta pelatihan keterampilan pembuatan kerajinan resin. Diskusi kewirausahaan dilaksanakan menggunakan analisis SWOT. Menurut Rangkuti (2005:18), Analisis SWOT merupakan suatu identifikasi berbagai faktor secara sistematis untuk merumuskan strategi perusahaan. Analisis ini didasarkan pada logika yang dapat memaksimalkan kekuatan (strengths) dan peluang (opportunities), dan secara bersamaan dapat meminimalisir kelemahan (weaknesses) dan ancaman (threats).

Secara keseluruhan kegiatan ini dilaksanakan selama 3 bulan, diawali dengan persiapan dan koordinasi hingga dilaksanakannya pelatihan selama satu hari serta evaluasi dan pembuatan laporan seperti alur kegiatan pada tabel di bawah ini.

Tabel 1. Alur kegiatan pengabdian

\begin{tabular}{lll}
\hline \multicolumn{1}{c}{ Peran Tim Pelaksana } & \multicolumn{1}{c}{ Komponen Kegiatan } & Peran Mitra 1 dan Mitra 2 \\
\hline $\begin{array}{l}\text { Berkoordinasi dengan } \\
\text { stakeholder dan peserta serta } \\
\text { mempersiapkan materi }\end{array}$ & $\begin{array}{l}\text { Persiapan pelatihan } \\
\text { keterampilan }\end{array}$ & $\begin{array}{l}\text { Mempersiapkan tempat dan } \\
\text { mendata peserta }\end{array}$ \\
\hline $\begin{array}{l}\text { Sosialisasi dan memberi motivasi } \\
\text { berwirausaha. }\end{array}$ & $\begin{array}{l}\text { Sosialisasi dan motivasi } \\
\text { kewirausahaan }\end{array}$ & $\begin{array}{l}\text { Mitra 1 membuat kerajinan } \\
\text { tangan }\end{array}$ \\
$\begin{array}{l}\text { Memberi materi keterampilan } \\
\text { kerajinan resin }\end{array}$ & Pelatihan keterampilan & $\begin{array}{l}\text { Mitra 2 berkoordinasi dengan tim } \\
\text { pelaksana }\end{array}$ \\
\hline $\begin{array}{l}\text { Memberikan saran terhadap } \\
\text { hasil karya peserta dan } \\
\text { pengembangannya }\end{array}$ & Presentasi hasil karya & $\begin{array}{l}\text { Mempresentasikan hasil karya } \\
\text { peserta }\end{array}$ \\
\hline
\end{tabular}

\section{HASIL DAN PEMBAHASAN}

Dilaksanakan pada hari Minggu, 27 November 2016 dari pukul 09.00 wib s.d. 12.00 wib, kegiatan ini diadakan di Gedung PKK RVII. Pelatihan ini diikuti oleh 20 peserta. Mereka merupakan anggota PKK RW VII dan seluruh peserta adalah wanita. Kegiatan ini juga dihadiri oleh Kepala UPT Kawasan Gunung Tidar, Ketua RW VII
Kelurahan Magersari, dan Ketua PKK RW VII.

Dalam sambutannya, Ketua RW VII menuturkan bahwa minat para pemuda di daerah tersebut pada kegiatan pelatihan semacam itu sangatlah kurang. Mereka lebih memilih menjadi pengamen karena relatif mudah untuk mendapatkan uang daripada membuat kerajinan sebagai usaha. 
Hal tersebut dapat dilihat dari tidak adanya peserta pelatihan dari kalangan pemuda. Namun, kegiatan ini mendapat sambutan positif dari Ketua RW dan Ketua PKK.

Peserta yang hadir mampu memenuhi kuota kehadiran dengan prosentase $100 \%$. Pada materi pertama tentang wirausaha, terdapat beberapa peserta yang masih kurang jelas tentang analisa Threats. Sebenarnya banyak peserta yang sadar akan potensi yang dimiliki oleh lokasi tempat tinggal mereka. Namun, mereka kurang paham bagaimana memanfaatkan potensi yang ada dan menjadikannya sebagai peluang usaha. Setelah mengikuti diskusi kewirausahaan, mereka mulai paham akan peluang usaha yang mereka miliki. Hal tersebut terlihat dengan beberapa pertanyaan yang muncul terkait usaha kerajinan tangan, cara mengajukan proposal bantuan usaha kepada pemerintah, dan membuat souvenir yang unik khas Gunung Tidar. Menyadari bahwa analisis SWOT dalam bisnis dan pariwisata ini masih sangat asing bagi peserta, maka materi diberikan dengan bahasa sederhana. Dengan demikian, mereka dapat memahami materi diskusi yang dilakukan. Berikut ini adalah materi kewirausahaan yang didiskusikan melalui analisis SWOT.

Tabel 2. Analisis SWOT

\begin{tabular}{|c|c|}
\hline Aspek & Faktor \\
\hline Strengths & $\begin{array}{l}\text { Kuantitas SDM yang memadai Kawasan Wisata Gunung Tidar yang } \\
\text { banyak dikunjungi wisata }\end{array}$ \\
\hline Weaknesses & $\begin{array}{l}\text { Modal yang terbatas } \\
\text { Keterampilan yang terbatas } \\
\text { Keterbatasan kemampuan dan strategi promosi hasil karya } \\
\text { Mental bekerja yang kurang dari masyarakat }\end{array}$ \\
\hline Opportunities & $\begin{array}{l}\text { Dukungan pariwisata dari pemerintah } \\
\text { Kerajinan tangan yang kian diminati }\end{array}$ \\
\hline Threats & Persaingan usaha souvenir yang kian ketat \\
\hline
\end{tabular}

Sedangkan pada materi ke-2 tentang motivasi, seluruh peserta tampak antusias dan termotivasi untuk berwirausaha. Hal ini tampak pada semangat mereka mengikuti pelatihan hingga selesai setelah memperoleh gambaran tentang berwirausaha. Pada materi ke-3, seluruh peserta berhasil membuat produk gantungan kunci dari bahan resin. Pada saat kegiatan pembuatan kerajinan, banyak peserta yang antusias mengikuti cara pembuatannya. Seluruh peserta aktif dan saling berkreasi dengan menghias adonan resin dengan isian yang telah disediakan berupa manik-manik dan bunga pita. Pada awalnya mereka mengalami kesulitan dalam membuat adonan karena ini merupakan pertama kali bagi mereka membuat kerajinan tangan dari resin. Setelah beberapa kali percobaan, mereka mulai mengetahui perbandingan yang sesuai antara resin dan katalis untuk membuat adonan. Beberapa cetakan telah disediakan dalam berbagai bentuk. Berikut ini adalah gambar kegiatan peserta pada saat membuat kerajinan resin.

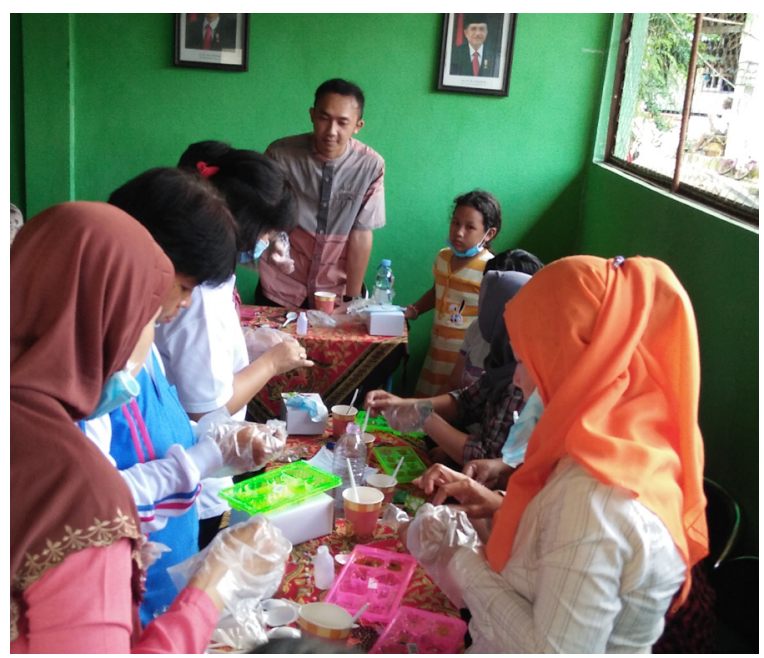

Gambar 2. Pembuatan kerajinan resin

Secara umum, terdapat perbedaan kondisi peserta sebelum dan sesudah 
mengikuti pelatihan. Kondisi tersebut meliputi gambaran umum berwirausaha, motivasi berwirausaha, dan keterampilan membuat kerajinan resin. Perbedaan tersebut dijelaskan pada tabel berikut ini.

Tabel 3. Kondisi sebelum dan sesudah pelaksanaan pelatihan

\begin{tabular}{lll}
\hline \multicolumn{1}{c}{ Uraian } & \multicolumn{1}{c}{ Kondisi sebelum kegiatan } & \multicolumn{1}{c}{ Kondisi setelah kegiatan } \\
\hline $\begin{array}{l}\text { Gambaran } \\
\text { umum tentang } \\
\text { berwirausaha }\end{array}$ & $\begin{array}{l}\text { Belum memiliki gambaran } \\
\text { berwirausaha di lokasi wisata } \\
\text { Gunung Tidar }\end{array}$ & $\begin{array}{l}\text { Mengetahui peluang, potensi, serta } \\
\text { hambatan berwirausaha di lokasi wisata } \\
\text { Gunung Tidar }\end{array}$ \\
\hline $\begin{array}{l}\text { Motivasi } \\
\text { berwirausaha }\end{array}$ & Kurang semangat berwirausaha & $\begin{array}{l}\text { Antusias dan semangat mengikuti diskusi } \\
\text { tentang wirausaha }\end{array}$ \\
$\begin{array}{l}\text { keterampilan } \\
\text { membuat kerajinan } \\
\text { resin }\end{array}$ & $\begin{array}{l}\text { Belum mengetahui bahan, alat, } \\
\text { dan cara membuat kerajinan } \\
\text { resin }\end{array}$ & $\begin{array}{l}\text { Mengetahui bahan dan alat, serta cara } \\
\text { berkreasi dengan bahan dasar resin, seperti } \\
\text { gantungan kunci. }\end{array}$ \\
\hline
\end{tabular}

Sasaran pelatihan keterampilan pembuatan kerajinan resin ini adalah anggota PKK RW VII Kelurahan Magersari Kota Magelang. Semua peserta mengikuti seluruh rangkaian kegiatan pelatihan. Berdasarkan hasil pengamatan, perbedaan kondisi sebelum dan sesudah pelatihan, terdapat perubahan baik dari aspek pengetahuan, attitude, dan keterampilan. Melalui diskusi, mereka mengetahui potensi, kelemahan, peluang, dan langkah yang dapat mereka lakukan dalam berwirausaha. Selain itu, mereka termotivasi untuk berwirausaha dengan memanfaatkan potensi dari lokasi wisata Gunung Tidar serta keterampilan yang mereka miliki. Terlihat peningkatan minat mereka terhadap usaha kerajinan tangan. Pelatihan ini juga memberi pengetahuan dan keterampilan mereka dalam membuat kerajinan resin. Berikut ini adalah gambar hasil karya peserta.

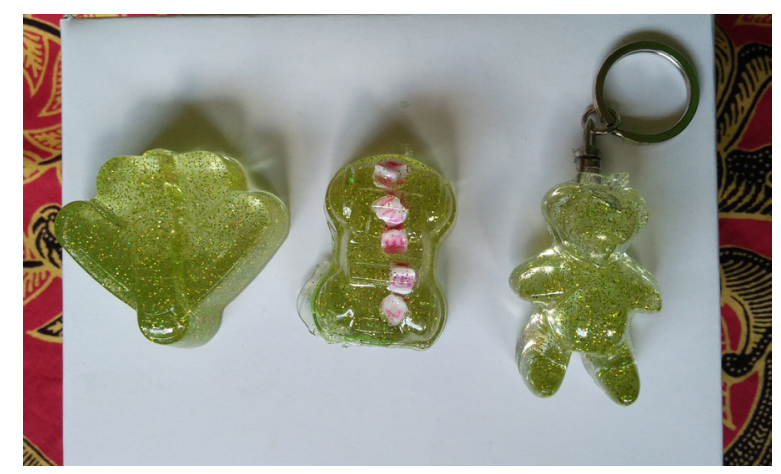

Gambar 3. Hasil Karya Peserta

Pada dasarnya mereka memiliki kemauan dan minat yang besar terhadap pelatihan keterampilan semacam ini. Terlihat dari hasil karya mereka dan cara mereka membuatnya menunjukkan bahwa mereka mampu. Namun, beberapa peserta perlu pendampingan dan arahan agar menghasilkan kerajinan resin yang diharapkan.

Hasil dari pelatihan keterampilan kerajinan resin ini secara umum dapat dikatakan berhasil.

\section{SIMPULAN DAN SARAN}

\section{Simpulan}

Berdasarkan uraian hasil dan pembahasan di atas, maka dapat disimpulkan bahwa:

1. Pelatihan pembuatan kerajinan resin ini telah berhasil memberi wawasan tentang potensi dan peluang usaha serta motivasi kepada peserta untuk berwirausaha di kawasan Gunung Tidar. Pelatihan ini juga berhasil memberi keterampilan untuk membuat souvenir kerajinan tangan berupa gantung kunci. Seluruh peserta mampu membuatnya secara baik dengan memanfaatkan manik-manik dan glitter.

2. Tanggapan siswa terhadap pelaksanaan kegiatan pelatihan pembuatan kerajinan resin ini sangat baik. Hal ini dapat dilihat dari kehadiran peserta mencapai $100 \%$ dari target, dan selama kegiatan berlangsung mereka sangat antusias mengikuti kegiatan dari awal sampai akhir kegitan. 


\section{Saran}

Pelatihan kerajinan resin di RW VII Kelurahan Magersari Kota Magelang ini mendapat sambutan positif dari warga dan pengelola Kawasan Gunung Tidar. Keterampilan pembuatan kerajinan resin ini diharapkan akan terus dikembangkan baik dari variasi bentuk maupun kegunaan. Selain itu, melihat potensi lokasi Wisata Gunung Tidar ini, peserta diharapkan dapat memanfaatkan keterampilan yang mereka peroleh sebagai peluang usaha. Melihat sambutan dan motivasi mereka yang positif, perlu adanya tindak lanjut dari dinas terkait untuk ikut serta mengembangkan kerajinan souvenir di lokasi wisata ini. Pelatihan terkait pengembangan usaha pun perlu diadakan, seperti pemasaran, dan permohonan kerjasama atau bantuan usaha sehingga pelatihan semacam ini dapat berjalan secara berkesinambungan.

\section{DAFTAR PUSTAKA}

Badan Perencanaan Pembangunan Nasional. 2014. Pembangunan Priwisata 2015-2019. Jakarta.

Carlton, C. 1982. Castin' Craft Idea Book. California: Environmental Technology Inc.

Haryono, A. 2011. Pemanfaatan Fiberglass untuk Pembuatan Body Plastik Kendaraan. Jurnal Politeknosains, Vol. 10 No. 1. www.ejournal.politama.ac.id/index.php/politeknosains/ article/viewFile/30/27. Diakses 1 Juli 2016.

Kantor Penanaman Modal Kota Magelang. 2015. Kawasan Gunung Tidar. http://kpm. magelangkota.go.id/investasi/potensi-investasi/302-kawasan-gunung-tidar . Diakses 3 Juli 2016.

Kartika, I.R., dkk. 2015. Pelatihan Pembuatan Case Gadget Chemistry Style yang Unik dan Kreatif dalam Rangka Meningkatkan Keterampilan Mahasiswa Jurusan Kimia FMIPA UNJ. Sarwahita Jurnal Pengabdian Masyarakat, No. 12 Vol. 2 ISSN 0216 - 7484. unj. ac.id/lpm/wp.../Jurnal-Sarwahita-Vol-12-No-2-Mei-2015-rev-WEB-Cry-ok.pdf. Diakses 1 Juli 2016.

Kementerian Pariwisata Republik Indonesia. 2016. Laporan Akuntabilitas $K i n$ e $r$ j a Kementerian Pariwisata Tahun 2015. Jakarta.

Rangkuti, F. 2005. Analisis SWOT: Teknik Membedah Kasus Bisnis. Jakarta: PT. Gramedia 